\title{
PELATIHAN MODIFIKASI FOOTWORK TERHADAP PENINGKATAN KELINCAHAN SISWA SMP NEGERI 3 ABIANSEMAL BADUNG BALI
}

\author{
Maryoto Subekti ${ }^{1}$, I Gusti Putu Ngurah Adi Santika ${ }^{2}$ \\ 1,2 Prodi Pendidikan Jasmani Kesehatan dan Rekreasi, Universitas PGRI Mahadewa Indonesia \\ E-mail: maryotosubekti9@gmail.com¹, ngurahadisantika@gmail.com² \\ DOI: https://doi.org/10.36526/kejaora.v6i1.1288
}

\begin{abstract}
ABSTRAK
Berdasarkan observasi tingkat kelincahan siswa SMPN 3 Abiansemal khususnya yang menekuni cabang olahraga bulutangkis memiliki kemampuan kelincahan yang kurang. Berdasarkan hal tersebut maka peneliti melaksanakan penelitian yang bertujuan untuk meningkatkan kelincahan tubuh siswa dengan memberikan pelatihan modifikasi footwork. Design penelitian yang dipergunakan adalah Pre and Post Test Gorup Design yang terdiri atas dua kelompok yaitu kelompok perlakuan dan kelompok kontrol. Jumlah sampel dalam penelitian ini adalah 40 orang yang diambil dari peserta ekstrakurikuler bulutangkis SMPN 3 Abainsemal Badung Bali. Hasil penelitian diperoleh rerata tes awal kelompok kontrol $17.03 \pm 1.115$ detik dan rerata tes akhir kelompok kontrol $14.95 \pm 0.448$ detik dengan perbedaan rerata pre dan post test pada kelompok kontrol 2.08 detik dengan $(p<0.05)$. Sedangkan pada kelompok perlakuan diperoleh rerata tes awal $17.17 \pm 0.858$ detik dan rerata tes akhir $14.67 \pm 0.700$ detik dengan perbedaan rerata pre dan post test pada kelompok perlakuan 2.50 detik dengan $(p<0.05)$. Kesimpulan dari penelitian ini adalah pelatihan modifikasi footwork dapat meningkatkan kelincahan siswa SMPN 3 Abiansemal.
\end{abstract}

Kata Kunci: Agility; Footwork Modification; Badminton

\section{PENDAHULUAN}

Setiap aktivitas pasti mempunyai tujuan, tidak terkecuali dengan aktivitas olahraga. Tujuan berolahraga dapat dibagi atas kebutuhannya yaitu : untuk rekreasi (bersenang-senang), untuk pendidikan (pembinaan disiplin, keberminatan, kepribadian, dan kerjasama siswa), untuk kesehatan (pencegahan, pengobatan, dan rehabilitasi penyakit), untuk meningkatkan kebugaran jasmani (agar mampu melakukan pekerjaan sehari-hari dengan tingkat efisiensi dan produktifitas tinggi), dan untuk meningkatkan prestasi (menjadi juara olahraga) (Nala, 2016; Adiatmika \& Santika, 2016; Santika et al, 2020). Berdasarkan hal tersebut, pelaksanaan pelatihan olahraga akan berbeda-beda sesuai dengan tujuan yang hendak ingin dicapai (Santika et al, 2020).

Olahraga mempunyai peranan yang penting dalam kehidupan manusia. Melalui olahraga dapat dibentuk manusia yang sehat jasmani, rohani serta mempunyai kepribadian, disiplin, sportifitas yang tinggi sehingga pada akhirnya akan terbentuk manusia yang berkualitas. Peranan olahraga dalam hal ini memiliki andil yang cukup penting untuk membuat manusia menjadi sehat dan bugar, seperti apa yang tercermin dalam slogan mensana in corpore sano yang artinya di dalam tubuh yang sehat terdapat jiwa yang kuat. Olahraga adalah kegiatan fisik yang mengandung sifat permainan, dan berisi perjuangan dengan diri sendiri atau perjuangan dengan orang lain, atau konfrontasi dengan unsur-unsur alam (Tirtayasa, 2020).

Dari olah raga yang dilaksanakan, salah satu yang di gemari adalah permainan bulutangkis.

Pengertian bulutangkis/badminton adalah cabang olaharaga permainan yang dimainkan menggunakan raket dan shuttlecock (bulu) dengan cara memukul dan menangkis shuttlrcock agar tidak jatuh ke daerah sendiri (Zarwan et al., 2019). Hal inilah yang menyebabkan penamaan olahraga 
Jurnal Kejaora: Jurnal Kesehatan Jasmani dan Olah Raga

ISSN: 2541-5042 (Online)

ISSN: 2503-2976 (Print)

Volume 6 Nomor 1, Edisi April 2021

bulutangkis menjadi permainan bulutangkis. Teknik yang paling dasar dari permainan bulutangkis adalah memegang raket dengan benar dan footwork (Nando et al., 2018).

Untuk mencapai prestasi yang optimal di dalam olahraga memerlukan waktu pembinaan yang lama dan harus sudah di mulai sejak usia dini, serta melalui pendekatan ilmiah. Untuk mencapai prestasi, salah satu faktor yang turut menuntun adalah memiliki kebugaran fisik untuk mencapai prestasi yang optimal (Sumerta et al., 2021). Pada dasarnya pelatihan kelincahan tidak begitu gampang, sebab banyak hal yang harus di pelajari terutama yang menyangkut teknik dasar pelatihan ini. Karena itu kelincahan dibutuhkan oleh peserta ekstrakulikuler SMPN 3 Abiansemal dalam menghadapi situasi tertentu dan disaat kondisi pertandingan yang menuntut unsur kelincahan yang optimal dalan bergerak untuk dapat memukul cock. Tetapi pada kenyataannya, peserta ekstrakulikuler Bulutangkis SMPN 3 Abiansemal belum memiliki kelincahan yang optimal dalam mengikuti pertandingan Bulutangkis. Hal itu di kerenakan dari berbagai metode pelatihan belum dikatakan secara pasti metode mana yang paling baik untuk melatih kelincahan. Maka dari itu, diperlukan suatu penelitian yang dapat memberikan solusi mengenai metode pelatihan yang tepat digunakan maka tujuan yang ingin dicapai dalam penelitian ini adalah untuk mengetahui ada tidaknya peningkatan kelincahan melalui pelatihan modifikasi footwork.

\section{METODE}

Penelitian ini dilaksanakan di Lapangan Bulutangkis SMPN 3 Abiansemal Badung Bali dengan frekuensi 4 kali seminggu yaitu pada hari Senin, Rabu, Jumat dan Sabtu pada pukul 14.00 WITA. Populasi dalam penelitian ini adalah peserta ekstrakurikuler bulutangkis sebanyak 40 orang. Sampel diperoleh berdasarkan teknik Populasi Studi yaitu mengambil keseluruhan populasi yang ikut dalam ekstrakurikuler bulutangkis kelompok umur 13-15 tahun dengan jenis kelamin laki-laki. Penelitian ini merupakan penelitian eksperimental dengan rancangan Pre and Post Test Gorup Design

(Sugiyono, 2013). Pola penelitian yang dipergunakan adalah dengan membagi populasi ke dalam dua kelompok untuk diberikan dua pelatihan yang berbeda.

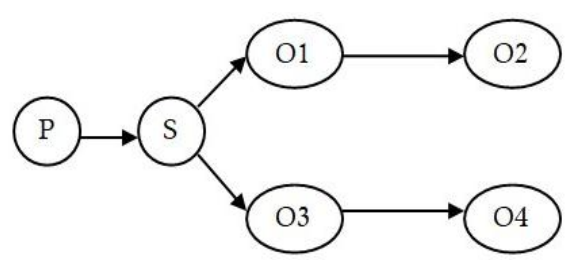

Gambar 1. Desain Penelitian (Sugiyono, 2013)

Metode analisis data yang dipergunakan diantaranya : 1) uji deskriptif statistik untuk menganalisis rerata, SB, minimum dan maksimum, 2) uji normalitas data dengan Shapiro Wilk Test yang bertujuan untuk mengetahui normalitas data kelincahan masing-masing kelompok perlakuan dan kontrol, 3) uji homogenitas dengan Levene's Test bertujuan untuk mengetahui homogenitas data pengukuran kelincahan pada masing-masing kelompok, 4) ujit-paired dipergunakan untuk menganalisis rerata perubahan hasil pengukuran kelincahan antara sebelum dan sesudah pelatihan pada masing-masing kelompok dan 5) uji T-Independent dipergunakan untuk menganalisis rerata perubahan antar kelompok perlakuan dan kontrol sebelum dan sesudah pelatihan.

\section{HASIL DAN PEMBAHASAN}

Berdasarkan hasil uji normalitas data (Shapiro-wilk test) pada kelincahan tubuh sebelum dan sesudah pelatihan pada kelompok perlakuan dan kontrol menunjukan bahwa data pada kedua kelompok memiliki nilai $p$ lebih besar dari $0,05 \quad(p>0,05)$, sehingga dinyatakan data berdistribusi normal. Demikian pula hasil uji homogenitas dengan (Levene Test) menunjukkan bahwa data pada ke dua kelompok berdasarkan hasil pengukuran kelincahan tubuh berdistribusi homogen karena nilai $p$ lebih besar dari $0,05 \quad(p>0,05)$. Berikut tabel uji normalitas dan homogenitas data kelincahan tubuh. 
Jurnal Kejaora: Jurnal Kesehatan Jasmani dan Olah Raga

ISSN: 2541-5042 (Online)

ISSN: 2503-2976 (Print)

Volume 6 Nomor 1, Edisi April 2021

Tabel 1. Hasil Uji Normalitas dan Homogenitas Data Kelincahan Tubuh Sebelum dan Sesudah Pelatihan Pada Kedua Kelompok

PengukuranKelincahan Uji Normalitas (Saphiro Wilk-Test) Uji Homogenitas (Levene-

Tubuh Test) Nilai $p$

$\begin{array}{ll}\text { Klp Kontrol } & \text { Klp } \\ \text { Nilai p } & \text { PerlakuanNilai } p\end{array}$

Tes Awal

0.417

0.053

0.547

Tes Akhir

0.344

0.010

0.362

Uji t-paired dipergunakan untuk mengetahui dampak atau efek yang dihasilkan dari pelatihan yang diberikan pada masing-masing kelompok yang dilihat dari rerata kelincahan tubuh sebelum dan sesudah pelatihan pada kelompok perlakuan (modifikasi footwork) dan kontrol (footwork). Dari kedua kelompok dilakukan uji rerata perbedaan peningkatan kelincahan tubuh sebelum dan sesudah pelatihan dan diperoleh data sesuai dengan tabel berikut :

Tabel 2. Uji Rerata Perbedaan Efek Pelatihan Sebelum dan Sesudah Pelatihan Pada MasingMasing Kelompok

\begin{tabular}{|c|c|c|c|c|c|c|c|c|}
\hline \multicolumn{2}{|c|}{ Penqukuran Kelincahan Tubuh } & Min. & Max. & Rerata & SB & Beda & $\mathrm{t}$ & \\
\hline \multirow{2}{*}{ Kelompok Kontrol } & Tes Awal & 15.38 & 19.25 & 17.03 & 1.115 & \multirow[t]{2}{*}{2.08} & \multirow{2}{*}{8.356} & \multirow{2}{*}{0,000} \\
\hline & Tes Akhir & 14.22 & 15.91 & 14.95 & 0.448 & & & \\
\hline \multirow{3}{*}{ Kelompok Perlakuan } & & & & & & & & \\
\hline & Tes Awal & 15.78 & 18.33 & 17.17 & 0.858 & \multirow[t]{2}{*}{2.50} & \multirow[t]{2}{*}{10.574} & \multirow[t]{2}{*}{0,000} \\
\hline & Tes Akhir & 13.84 & 15.96 & 14.67 & 0.700 & & & \\
\hline
\end{tabular}

Grafik perbedaan efek pelatihan terhadap kekuatan otot perut dapat dilihat pada grafik berikut ini :

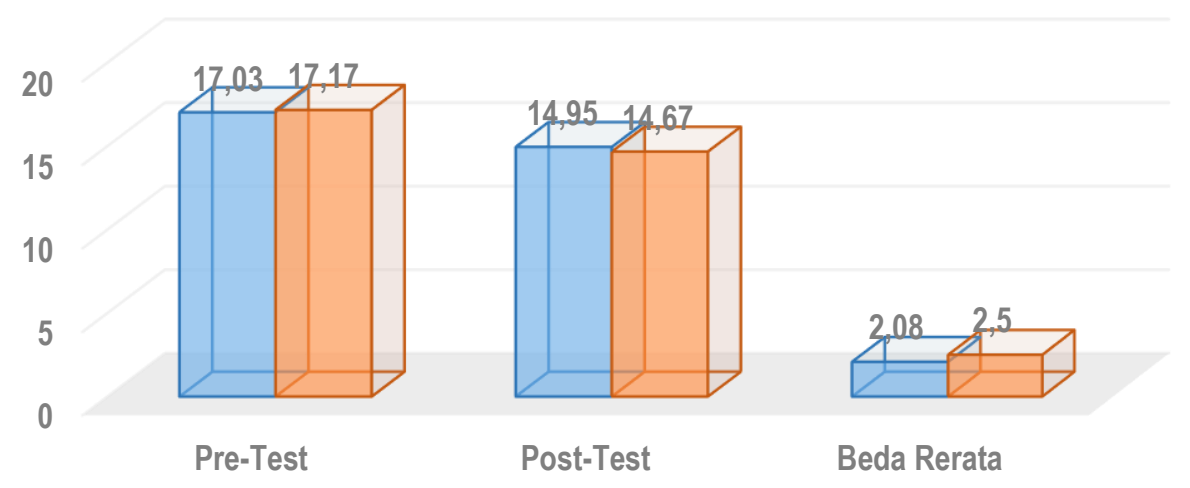

$\square$ KIp.Kontrol $\square$ KIp.Perlakuan

Gambar 2. Grafik Efek Pelatihan Terhadap Kelincahan Tubuh Pada Masing-Masing Kelompok

Berdasarkan data yang tertera pada tabel 2, diperoleh rerata tes awal kelompok kontrol $17.03 \pm 1.115$ detik dan rerata tes akhir kelompok kontrol $14.95 \pm 0.448$ detik dengan perbedaan rerata pre dan post test pada kelompok kontrol 2.08 detik dengan $(p<0.05)$. Sedangkan pada kelompok perlakuan diperoleh rerata tes awal $17.17 \pm 0.858$ detik 
Jurnal Kejaora: Jurnal Kesehatan Jasmani dan Olah Raga

ISSN: 2541-5042 (Online)

ISSN: 2503-2976 (Print)

Volume 6 Nomor 1, Edisi April 2021

dan rerata tes akhir $14.67 \pm 0.700$ detik dengan perbedaan rerata pre dan post test pada kelompok perlakuan 2.50 detik dengan $(p<0.05)$.

Berdasarkan tabel dan grafik di atas menunjukkan bahwa perbedaan rerata kekuatan otot perut pada kelompok perlakuan dan kontrol sebelum dan sesudah pelatihan menunjukan nilai $p$ lebih kecil dari 0,05 $(p<0,05)$. Sehingga nilai tersebut menyatakan

ada perbedaan yang bermakna antara sebelum dan sesudah pelatihan pada masing-masing kelompok.

Sedangkan untuk mengetahui seberapa besar dampak yang dihasilkan dari pelatihan modifikasi footwork antar kelompok perlakuan dan kontrol sebelum dan sesudah pelatihan maka dapat dilihat pada tabel berikut :

Tabel 3. Data Uji Perbedaan Efek Antar Kelompok Dengan T-Test Independent

\begin{tabular}{llllll}
\hline & Kelompok & Rerata & $\mathrm{t}$ & $\mathrm{p}$ & Beda Rerata \\
\hline Post-test & Kontrol & 14.95 & 2.095 & 0.044 & 0.28 \\
\cline { 2 - 3 } & Perlakuan & 14.67 & & & \\
\hline
\end{tabular}

Berdasarkan tabel 3 rerata pelatihan footwork pada kelompok kontrol sebesar 14.95 detik sedangkan rerata pada kelompok kontrol 14.67 detik dengan beda rerata 0.28 detik dan nilai $(p<0.05)$. ini berarti terdapat perbedaan yang bermakna antara pelatihan modifikasi footwork pada kelompok perlakuan dengan pelatihan footwork pada kelompok kontrol.

Tabel 4. Persentase Perubahan Kelincahan Tubuh Sesudah Pelatihan

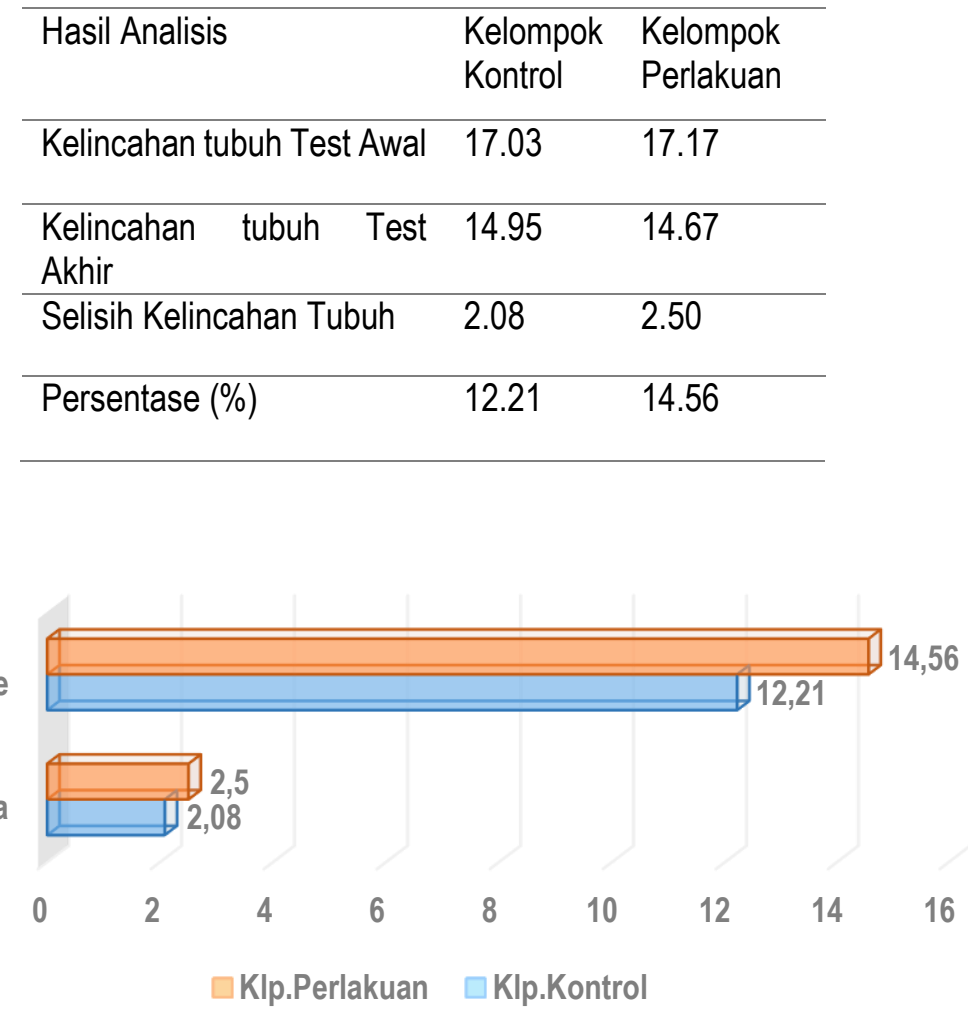

Gambar 3. Grafik Persentase Perubahan Kekuatan Otot Perut Sesudah Pelatihan

Berdasarkan tabel 4 terlihat bahwa peningkatan kelincahan tubuh pada kelompok kontrol sebesar $12.21 \%$ sedangkan pada kelompok perlakuan sebesar $14.56 \%$. 
Jurnal Kejaora: Jurnal Kesehatan Jasmani dan Olah Raga

ISSN: 2541-5042 (Online)

ISSN: 2503-2976 (Print)

Volume 6 Nomor 1, Edisi April 2021

Hal ini menunjukkan bahwa pelatihan modifikasi footwork dapat memberikan peningkatan kelincahan tubuh lebih baik daripada pelatihan footwork. Manfaat yang diperoleh oleh peserta ekstrakurikuler bulutangkis SMPN 3 Abiansemal Badung adalah para siswa yang sebelumnya memiliki kendala dalam hal kelincahan tubuh menjadi terbantu dengan diterapkannya pelatihan modifikasi footwork. Kelebihan dari pelatihan modifikasi footwork adalah gerakan atlet menjadi terstruktur dengan baik karena dalam pelatihan modifikasi footwork menekankan pada hal sebagai berikut : 1) arah perpindahan badan tervariasi kesegala arah, 2) atlet mengatur posisi tubuh dengan dengan berat badan bertumpu pada kedua kaki dengan tetap menjaga keseimbangan tubuh, 3) kaki dibuka selebar bahu dengan sejajar salah satu kaki di depan kaki lainnya, tekuk kedua lutut berdiri pada ujung kaki sehingga posisi pinggang tetap tegak dan rileks, 4) kedua lengan siku bengkok pada posisi disamping badan sehingga lengan bagian atas yang memegang tetap bebas bergerak, 5) raket dipegang dengan rileks dan pada posisi kepala (daunnya) raket lebih tinggi dari kepala, 6) bergerak kedepan, kebelakang, kanan, kiri serta sudut depan kanan kiri dan sudut belakang kanan kiri dengan tetap menjaga keseimbangan tubuh, 7) gerakan langkah perpindahan posisi tubuh di setiap arah dilakukan dengan cepat, 8) dilarang bertumpu pada telapak kaki pada saat memukul maupun menunggu cock. Dengan ketentuan yang telah ditetapkan pada pelatihan modifikasi footwork membuat tubuh akan beradaptasi dengan tetap berpindah dengan cepat dan seimbang sehingga atlet tidak akan kehilangan moment dalam mengantisipasi shutlecock. Dengan demikian kualitas pukulan shutlecock akan tetap terjaga (Astrawan et al., 2016).

Kekurangan dari pelatihan modifikasi footwork adalah terletak pada kondisi daya tahan kardiovaskuler atlet. Mengingat pelatihan footwork merupakan pelatihan intensitas tinggi dimana dibutuhkan kelincahan serta kecepatan dimana tubuh lebih banyak bekerja pada sistem anaerob maka daya tahan tubuh sangat dibutuhkan. Bagi atlet yang memiliki daya tahan tubuh

kurang akan sulit untuk mengikuti pelatihan ini. Ini karena daya tahan kardiovaskuler merupakan pondasi dalam melakukan aktivitas fisik (Santika, 2015). Berkaitan dengan hal itu maka apabila ingin melaksanakan pelatihan modifikasi footwork harus mempersiapkan kondisi daya tahan kardiovaskulernya.

Dengan adanya pelatihan modifikasi footwork membuat pelatihan ini disejajarkan dengan pelatihan yang berkaitan dengan kelincahan tubuh lainnya, seperti : pelatihan lari amplop yang dilakukan oleh Pratama (Pratama et al., 2016), pelatihan double dot drill yang dilakukan oleh Suryanata (Suryanata et al., 2018), pelatihan Ickey Shuffle yang dilakukan oleh Padmawan (Padmawan et al., 2010), pelatihan run star yang dilakukan oleh Santika (Santika et al., 2020) yang kesemuanya dapat meningkatkan kelincahan tubuh.

Namun sekarang kembali kepada kita sebagai pelaku olahraga, baik sebagai atlet atau pelatih yang beraktivitas dalam kaitannya meningkatkan kemampuan kelincahan tubuh untuk mempergunakan opsi yang mana. Mengingat ilmu akan terus berkembang maka hendaknya kita dapat menyesuaikan dengan keinginan dan kebutuhan yang kita inginkan.

\section{KESIMPULAN}

Berdasarkan hasil dan pembahasan yang telah dipaparkan maka dapat disimpulkan bahwa pelatihan modifikasi footwork dapat meningkatkan kelincahan tubuh siswa SMPN 3 Abiansemal. Saran peneliti terutama bagi para guru, pelatih serta dosen yang membidangi kepelatihan khususnya dalam hal melatih kelincahan tubuh pada cabang olahraga bukutangkis dapat mempergunakan pelatihan modifikasi footwork untuk meningkatkan kelincahan tubuh.

\section{DAFTAR PUSTAKA}

Adiatmika, IPG dan Santika, IGPNA. (2016). Bahan Ajar Tes dan Pengukuran Olahraga. Denpasar : Udayana University Press 
Jurnal Kejaora: Jurnal Kesehatan Jasmani dan Olah Raga

ISSN: 2541-5042 (Online)

ISSN: 2503-2976 (Print)

Volume 6 Nomor 1, Edisi April 2021

Astrawan, I Putu; Adiputra, N; Jawi, I Made. PELATIHAN FOOTWORK BULUTANGKIS 10 REPETISI 2 SET LEBIH BAIK DIBANDINGKAN 5 REPETISI 4 SET UNTUK MENINGKATKAN KEKUATAN OTOT TUNGKAI DAN KELINCAHAN. Sport and Fitness Journal, [S.I.], oct. 2016. ISSN 2654-9182. Available at: <https://ocs.unud.ac.id/index.php/spor t/article/view/24035>. Date accessed: 15 apr. 2021.

Nala. (2016). Prinsip Pelatihan Fisik Olahraga. Denpasar : Udayana University Press

Nando, M. (2018). Pengaruh Latihan Ledder Drill (Agility) terhadap Kemampuan Footwork Bulutangkis Mahasiswa Unit Kegiatan Olahraga Universitas Negri Padang. Jurnal Performa Olahraga, $3(02), \quad 109$. https://doi.org/10.24036/jpo29019

Padmawan, I. P. R., Darmada, I. M., Widiantari, N. L. G., Santika, I. G. P. N. A., Ariawati, N. W., \& Segu, A. D. (2020). Pelatihan Ickey Shuffle Dengan Jarak 6 Meter 4 Repetisi 3 Set Terhadap Kelincahan Siswa Putra Kelas X SMA Negeri 2 Mengwi Badung. Jurnal Pendidikan Kesehatan Rekreasi, 6(1), 119-124. https://doi.org/10.5281/zenodo.36616 06

Pratama, Y. S., Parwata, Y., \& Santika, N. A. (2016). Pelatihan Lari Amplop Meningkatkan Kelincahan Siswa Putra Peserta Ekstra Kurikuler Pencak Silat SMA Dwijendra Denpasar Tahun Pelajaran 2015/2016. Jurnal Pendidikan Kesehatan Rekreasi, 2(2), 21-25. Retrieved from https://ojs.mahadewa.ac.id/index.php/ jpkr/article/view/190

Santika, I. G. P. N. A. (2015). Hubungan Indeks Massa Tubuh (IMT) Dan Umur Terhadap Daya Tahan Umum (Kardiovaskuler) Mahasiswa Putra Semester II Kelas A Fakultas Pendidikan Olahraga Dan Kesehatan IKIP PGRI Bali Tahun 2014. Jurnal Pendidikan Kesehatan Rekreasi, 1(1), 42-47. Retrieved from

https://ojs.ikippgribali.ac.id/index.php/j pkr/article/view/6

Santika, I. G. P. N. A. (2017). Pengukuran Komponen Biomotorik Mahasiswa Putra Semester V Kelas A Fakultas Pendidikan Olahraga Dan Kesehatan IKIP PGRI Bali Tahun 2017. Jurnal Pendidikan Kesehatan Rekreasi, 3(1), 85-92. Retrieved from https://ojs.ikippgribali.ac.id/index.php/j pkr/article/view/221

Santika, I. G. P. N. A., Adiatmika, I. P. G., \& Subekti, M. (2020). Training Of Run Star For Agility Volleyball Athlete Junior High School 2 Denpasar. Jp.Jok (Jurnal Pendidikan Jasmani, Olahraga Dan Kesehatan), 4(1), 128-141. https://doi.org/10.33503/jp.jok.v4i1.11 37

Soegiyanto, S. H. (2013). Sumbangan Power Otot Lengan, Kekuatan Otot Tangan, Otot Perut Terhadap Akurasi Lemparan. Journal of Sport Sciences and Fitness, 2(1), 56-61

Sugiyono. (2013). Metode Penelitian Kuantitatif, Kualitatif dan R\&D. Bandung : ALFABETA

Sumerta, I. K., Santika, I. G. P. N. A., Dei, A., Prananta, I. G. N. A. C., Artawan, I. K. S., \& Sudiarta, I. G. N. (2021). Pengaruh Pelatihan Circuit Training Terhadap Kelincahan Atlet Sepakbola. Jurnal Pendidikan Kesehatan Rekreasi, 7(1), 230-238. https://doi.org/10.5281/zenodo.44600 71

Suryanata, I., Yasa, I. M., \& Santika, I. N. A. (2018). Pelatihan Double Dot Drill 2 Repetisi 3 Set Meningkatkan Kelincahan Siswa Putra Peserta Ekstra Kurikuler Pencak Silat SMP Negeri 1 Kuta Selatan Tahun Pelajaran 2016/2017. Jurnal Pendidikan Kesehatan Rekreasi, 4(1), 33-38. Retrieved from https://ojs.mahadewa.ac.id/index.php/ jpkr/article/view/129

Tirtayasa, P. K. R., Santika, I. G. P. N. A., Subekti, M., Adiatmika, I. P. G., \& Festiawan. R. (2020). Barrier Jump Training to Leg Muscle Explosive 
Jurnal Kejaora: Jurnal Kesehatan Jasmani dan Olah Raga

ISSN: 2541-5042 (Online)

ISSN: 2503-2976 (Print)

Volume 6 Nomor 1, Edisi April 2021

Power. Jurnal ACTIVE : Jurnal of Physical Education, Sport, Health and Recreation, $9(3)$, https://journal.unnes.ac.id/sju/index.p $\mathrm{hp} / \mathrm{peshr} /$ article/view/41145

Zarwan, Z., \& Hardiansyah, S. (2019). Penyusunan Program Latihan Bulutangkis Usia Sekolah Dasar Bagi Guru PJOK. Jurnal JPDO, 2(1), 12-17. Retrieved from http://jpdo.ppj.unp.ac.id/index.php/jpd o/article/view/182 